\title{
Allocation Strategies for Seed Nitrogen and Phosphorus in an Alpine Meadow Along an Altitudinal Gradient on the Tibetan Plateau
}

\author{
Zhiqiang Wang ${ }^{1 \dagger}$, Haiyan Bu ${ }^{2 \dagger}$, Mingcheng Wang ${ }^{1}$, Heng Huang ${ }^{3 *}$ and Karl J. Niklas ${ }^{4}$ \\ 1 Institute for Advanced Study, Chengdu University, Chengdu, China, ${ }^{2}$ State Key Laboratory of Grassland Agro-Ecosystems, \\ School of Life Sciences, Lanzhou University, Lanzhou, China, ${ }^{3}$ Department of Environmental Science, Policy, \\ and Management, University of California, Berkeley, Berkeley, CA, United States, ${ }^{4}$ Plant Biology Section, School \\ of Integrative Plant Science, Cornell University, Ithaca, NY, United States
}

\section{OPEN ACCESS}

Edited by:

Diego F. Gomez-Casati, National University of Rosario,

Argentina

Reviewed by:

Jianshuang Wu,

Institute of Environment and Sustainable Development in Agriculture, Chinese Academy

of Agricultural Sciences, China

Vladimir Onipchenko, Lomonosov Moscow State University,

Russia

${ }^{*}$ Correspondence:

Heng Huang

henghuang@berkeley.edu

${ }^{\dagger}$ These authors have contributed equally to this work

\section{Specialty section}

This article was submitted to

Plant Nutrition,

a section of the journal

Frontiers in Plant Science

Received: 06 October 2020 Accepted: 19 November 2020 Published: 09 December 2020

Citation:

Wang Z, Bu H, Wang M, Huang $H$ and Niklas KJ (2020) Allocation

Strategies for Seed Nitrogen and Phosphorus in an Alpine Meadow Along an Altitudinal Gradient on the Tibetan Plateau.

Front. Plant Sci. 11:614644. doi: 10.3389/fpls.2020.614644
Nitrogen $(\mathrm{N})$ and phosphorus $(\mathrm{P})$ play important roles in many aspects of plant biology. The allocation of $\mathrm{N}$ and $\mathrm{P}$ in plant vegetative organs (i.e., leaves, stems, and fine roots) is critical to the regulation of plant growth and development. However, how these elements are allocated in seeds is unclear. The aim of this study was to explore the $\mathrm{N}$ and $\mathrm{P}$ allocation strategies of seeds in an alpine meadow along an altitudinal gradient. We measured the seed $\mathrm{N}$ and $\mathrm{P}$ contents of 253 herbaceous species in 37 families along an altitudinal gradient $(2,000-4,200 \mathrm{~m})$ in the east Tibetan alpine meadow. The geometric means of seed $\mathrm{N}$ and $\mathrm{P}$ concentrations and $\mathrm{N}: \mathrm{P}$ ratios were $34.81 \mathrm{mg} \mathrm{g}^{-1}$, $5.06 \mathrm{mg} \mathrm{g}^{-1}$, and 6.88 , respectively. Seed $\mathrm{N}$ and $\mathrm{P}$ concentrations varied across major taxonomic groups and among different altitude zones. N:P ratios showed no significant variations among different taxonomic groups with the exception of $\mathrm{N}$-fixing species. The numerical value of the scaling exponent of seed $\mathrm{N}$ vs. $\mathrm{P}$ was 0.73 , thus approaching $3 / 4$, across the entire data set, but varied significantly across major taxonomic groups. In addition, the numerical value of the scaling exponent of $\mathrm{N}$ vs. $\mathrm{P}$ declined from 0.88 in the high altitude zone to 0.63 in the low altitude zone. These results indicate that the variations in the numerical value of the scaling exponent governing the seed $N$ vs. $P$ scaling relationship varies as a function of major taxonomic groups and among different altitude zones. We speculate that this variation reflects different adaptive strategies for survival and germination in an alpine meadow. If true, the data presented here advance our understanding of plant seed allocation strategies, and have important implications for modeling early plant growth and development.

Keywords: allocation, alpine meadow, nitrogen, phosphorus, scaling exponent, seed

\section{INTRODUCTION}

Nitrogen $(\mathrm{N})$ and phosphorus $(\mathrm{P})$ are considered the most important resources regulating plant growth and development (Vitousek, 2004), and thus play pivotal roles in regulating community dynamics and ecosystem function (Güsewell, 2004; Vitousek et al., 2010). Nitrogen is linked with leaf photosynthesis rates and total carbohydrate storage in leaves, stems, and roots (Sterner and Elser, 2002), whereas phosphorus is directly involved in the production of DNA, RNA, 
and proteins (Sterner and Elser, 2002; Vrede et al., 2004). The allocation of $\mathrm{N}$ and $\mathrm{P}$ in plants therefore undoubtedly reflects fundamental adaptive strategies across different species and species groups, which in turn influence the material and energy cycles of ecosystems (Ågren, 2004; Elser et al., 2007). Thus, quantifying how these two elements are allocated in plants is essential to our understanding of ecosystem dynamics.

The allocation patterns of $\mathrm{N}$ and $\mathrm{P}$ in the major vegetative plant organs (i.e., leaves, stems, and fine roots) are of particular interest and have been extensively investigated. Prior work has shown that the $\mathrm{N}$ vs. $\mathrm{P}$ scaling relationship is described by a power function taking the form of $\mathrm{N}=\beta \mathrm{P}^{\alpha}$, where $\beta$ and $\alpha$ represent the normalization constant and the slope (i.e., the scaling exponent) of the log-log linear $\mathrm{N}$ vs. P regression curve, respectively (Wright et al., 2004; Niklas et al., 2005; Kerkhoff et al., 2006; Niklas and Cobb, 2006b). The scaling exponent $(\alpha)$ is a crucial parameter in any power function. In the context of the $\mathrm{N}$ vs. $\mathrm{P}$ scaling relationship, when the scaling exponent is less than unity (i.e., $\alpha<1$ ), plants require disproportionately more $\mathrm{P}$ than $\mathrm{N}$, perhaps to ensure rapid protein synthesis (as predicted by the growth rate hypothesis proposed by Elser et al., 2000; 2003), whereas when the scaling exponent is greater than unity (i.e., $\alpha>1$ ) the opposite trend holds true (McGroddy et al., 2004; Niklas et al., 2005; Kerkhoff et al., 2006).

It has been observed that the allocation of $\mathrm{N}$ and $\mathrm{P}$ in plant organs is consistent with fundamental stoichiometric theory (Wright et al., 2004; Kerkhoff et al., 2006; Reich et al., 2010), and some comprehensive studies have reported that the scaling exponent of the $\mathrm{N}$ vs. $\mathrm{P}$ scaling relationship is numerically constant across independently evolved lineages despite environmental differences. Nevertheless, there remains a debate as to the numerical value of the scaling exponent. For example, using extensive data sets for leaves, $2 / 3$ and 3/4power "laws" have been proposed by different workers (Reich and Oleksyn, 2004; Wright et al., 2004; Niklas, 2006a; Reich et al., 2010). Furthermore, based on 1890 observations of 763 terrestrial plant species, Wang et al. (2019) have proposed a 0.82-power "law" for global fine root $\mathrm{N}$ vs. P across different plant groups and ecosystems. Consequently, the scaling exponent for the $\mathrm{N}$ vs. $\mathrm{P}$ scaling relationship manifests statistically significant differences between leaves and fine roots. However, several studies have also reported $\mathrm{N}$ vs. $\mathrm{P}$ scaling exponents with statistically significantly different numerical values in leaves (McGroddy et al., 2004; Han et al., 2005; Niklas et al., 2005; Tian et al., 2018), stems (Kerkhoff et al., 2006; Wang et al., 2018; Zhang et al., 2018) and fine roots (Yuan et al., 2011; Geng et al., 2014; Zhao et al., 2016) for different taxonomic groups or geographical locations owing to different physiological growth strategies among species and responses to changes in the environment.

In contrast to studies that have focused on leaves, stems, or fine roots, comparatively little is known about how $\mathrm{N}$ and $\mathrm{P}$ are allocated in seeds, which play an important role in the plant life cycle and directly influence the perseverance of species in different environmental settings (Bewley, 1997; JiménezAlfaro et al., 2016). During the earlier stages of ontogeny, a series of morphological and physiological processes depend largely on seed reserves (i.e., endosperm or cotyledons; see
Muthukumar and Udaiyan, 2000). $\mathrm{N}$ and $\mathrm{P}$ reserves in seeds supply critical components for the synthesis of ribosomes, RNA, DNA, and proteins required for cell division, embryonic growth and development, and seedling establishment (Bewley, 1997; Slot et al., 2013; Bu et al., 2016). Given the importance of seed $\mathrm{N}$ and $P$ in early growth and survival, it is important to understand and quantify the $\mathrm{N}$ vs. $\mathrm{P}$ scaling relationship in seeds.

Previous studies have demonstrated that the $\mathrm{N}$ and $\mathrm{P}$ concentrations in seeds are influenced by many environmental factors, such as temperature (Xu et al., 2016), $\mathrm{CO}_{2}$ (He et al., 2005), light (Mathew et al., 2000) and latitude (de Frenne et al., 2011) that can change as a function of altitude. Consequently, environmental variations can exert selective pressures on seed mass, stock nutrient materials, and germination time, thereby resulting in different adaptive strategies (Lord, 1994). For example, Bu et al. (2018) found that altitude has a significant effect on $\mathrm{N}$ and $\mathrm{P}$ seed concentrations. Based on this limited information, we hypothesized that the $\mathrm{N}$ vs. $\mathrm{P}$ scaling relationship for seeds will vary as a function of altitude.

The Tibetan Plateau represents one of the largest alpine meadows in the world, wherein herbaceous species have adapted to high altitude and low temperature by evolving unique survival mechanisms such as small seed size (Turnbull et al., 2012), rapid growth and life history completion (Adler et al., 2014), and high nutrient concentrations (Körner, 1989). Thus, the Tibetan Plateau provides an ideal region to investigate the $\mathrm{N}$ and $\mathrm{P}$ allocation strategies of seeds. For this purpose, we compiled a dataset on paired measurements of $\mathrm{N}$ and $\mathrm{P}$ seed concentrations for herbaceous species growing along an altitudinal gradient $(2,000-4,200 \mathrm{~m})$ on the east Tibetan Plateau. These data were then used to answer three important questions: (1) do seed $\mathrm{N}$ and $\mathrm{P}$ concentrations and $\mathrm{N}: \mathrm{P}$ ratios differ across major taxonomic groups and among different altitude zones?, (2) is the seed $\mathrm{N}$ vs. $\mathrm{P}$ scaling relationship the same across major taxonomic groups?, and (3) does the numerical value of the scaling exponent governing $\mathrm{N}$ vs. $\mathrm{P}$ relationships change along an altitudinal gradient?

\section{MATERIALS AND METHODS}

\section{Study Site}

This study was conducted on the northeastern edge of the Tibetan Plateau in China $\left(100^{\circ} 44^{\prime}-104^{\circ} 45^{\prime} \mathrm{E}, 33^{\circ} 06^{\prime}-35^{\circ} 34^{\prime}\right.$, altitude: $2,000-4,200 \mathrm{~m}$ ) (Figure 1). The main vegetation is that of a typical alpine meadow. The climate is cold HumidAlpine (annual average temperature ranges from $1.2^{\circ} \mathrm{C}$ to $4.6^{\circ} \mathrm{C}$ and annual average precipitation ranges from $516 \mathrm{~mm}$ to $780 \mathrm{~mm}$ ), and growing season is short (from late May to late September) (Bu et al., 2018, 2019). The dominant species in alpine meadow are mainly from the Asteraceae, Cyperaceae, Fabaceae, Gentianaceae, Polygonaceae, Ranunculaceae, and Scrophulariaceae (Zhang et al., 2014).

\section{Seed Sampling and Measurement}

From late August to September in 2015, mature seeds of 253 species from 37 families were collected from four zones along 


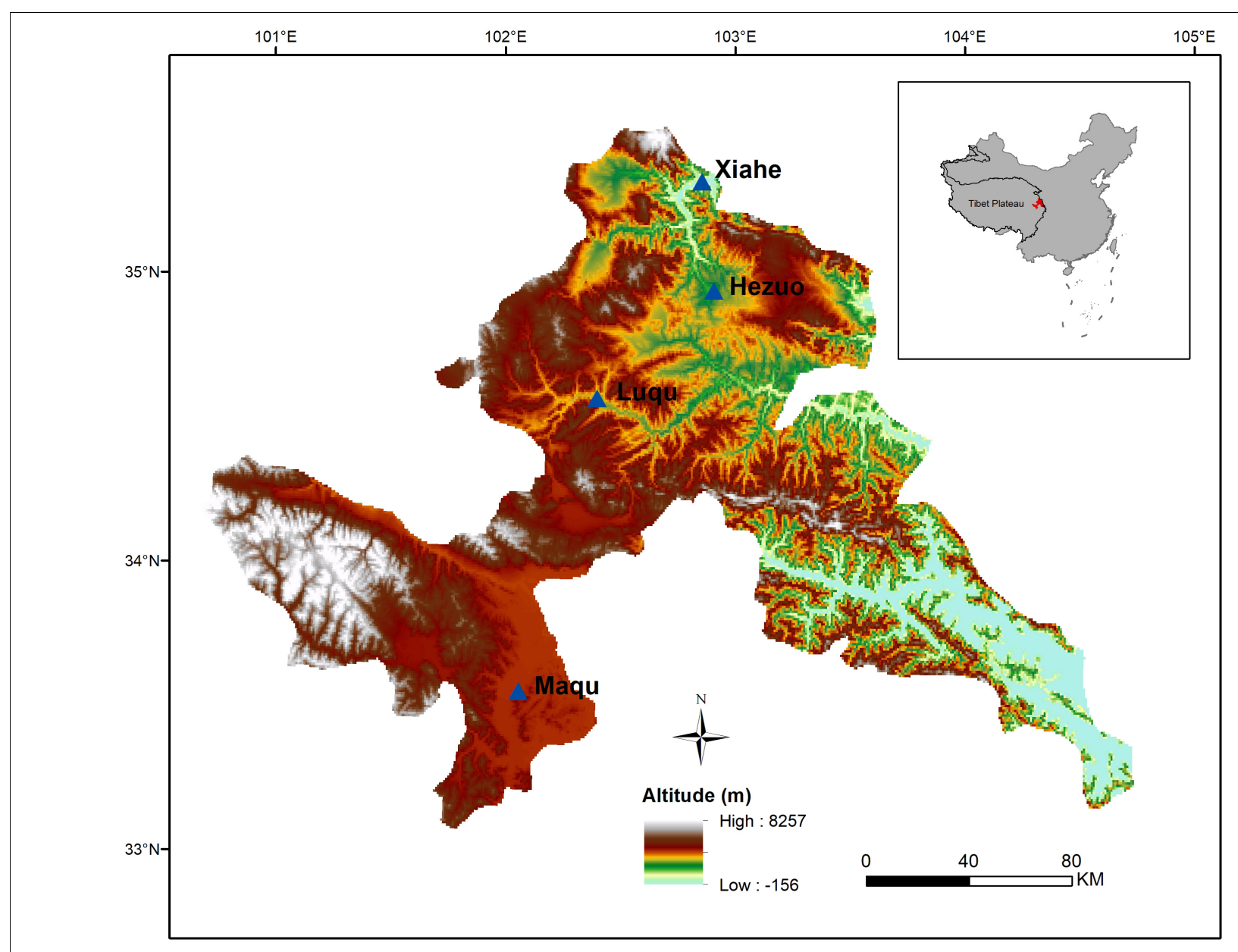

FIGURE 1| The study area and sample collection sites.

an altitudinal gradient $(2,000-4,200 \mathrm{~m})$. The time mature seeds were collected in different altitude zones based on extensive field observations on seed development and dispersal. Mature seeds were collected randomly from more than 30 individual conspecifics for each species from sites differing in $50 \mathrm{~m}$ across the altitude gradient, which was divided into four equal zones (see below).

Seeds were subsequently oven-dried at $50^{\circ} \mathrm{C}$ to a constant mass and ground into a fine powder. $\mathrm{N}$ and $\mathrm{P}$ concentrations were measured by dry combustion on an elemental analyzer (Elementar TOC Vario, Germany) and the molybdenum blue method on an automatic flow injection analyzer (Lachat Quickchem 8500, United States), respectively, as described by $\mathrm{Bu}$ et al. (2018). In total, the data set included 751 paired observations of $\mathrm{N}$ and $\mathrm{P}$ for seeds.

\section{Data Analysis}

The data were sorted into two life form groups (i.e., annual and perennial), two functional groups (i.e., forb and graminoid), two N-fixing groups (i.e., N-fixing and non-N-fixing), and two phylogenetic groups (i.e., monocotyledon and dicotyledon). The data were also divided into four altitude zones: Maqu
(3,400-4,200 m), Luqu (3,000-3,400 m), Hezuo (2,600-3,000 m) and Xiahe (2,000-2,600 m).

Differences in $\mathrm{N}$ and $\mathrm{P}$ concentrations and $\mathrm{N}: \mathrm{P}$ ratios across major taxonomic groups and among the four altitude zones were assessed using one-way analysis of variance (ANOVA) with least-significant difference (LSD) post hoc tests. Reduced major axis (RMA) regression using the lodel2 function in 'Imodel2' package was used to determine the numerical values of $\mathrm{N}$ vs. $\mathrm{P}$ scaling exponents for the major taxonomic groups and altitude zones using $\log _{10}$-transformed values of $\mathrm{N}$ and $\mathrm{P}$ concentrations (Warton et al., 2006; Legendre, 2018). A likelihood-ratio test method was used to assess the heterogeneity of RMA scaling exponents within the aforementioned groupings and altitude zones. All statistical analyses were performed using SPSS v20 (SPSS Inc., United States) and the statistical software R 2.15.2 (R Development Core Team, 2015).

\section{RESULTS}

We found that $\mathrm{N}$ and $\mathrm{P}$ concentrations differed across major taxonomic groups (Table 1 and Figure 2). For example, N 
TABLE 1 | Geometric means of seed N, P concentrations and N:P ratios for major taxonomic groups and altitude zones.

\begin{tabular}{lcccc}
\hline Taxonomic group & $\boldsymbol{n}$ & $\mathbf{N}$ & $\mathbf{P}$ & $\mathbf{N}: \mathbf{P}$ \\
\hline All & 751 & $34.81(0.47)$ & $5.06(0.09)$ & $6.88(0.13)$ \\
Life form groups & & & & \\
Annual & 188 & $31.03(0.60) \mathrm{b}$ & $4.86(0.16) \mathrm{a}$ & $6.38(0.31) \mathrm{a}$ \\
Perennial & 563 & $36.17(0.58) \mathrm{a}$ & $5.12(0.10) \mathrm{a}$ & $7.06(0.13) \mathrm{a}$ \\
Functional groups & & & & \\
Forb & 714 & $35.56(0.48) \mathrm{a}$ & $5.18(0.09) \mathrm{a}$ & $6.87(0.13) \mathrm{a}$ \\
Graminoid & 37 & $22.62(1.57) \mathrm{b}$ & $3.17(0.33) \mathrm{b}$ & $7.15(0.60) \mathrm{a}$ \\
N-fixation groups & & & & \\
N-fixing & 57 & $57.08(1.75) \mathrm{a}$ & $5.04(0.28) \mathrm{a}$ & $11.33(0.61) \mathrm{a}$ \\
Non-N-fixing & 694 & $33.42(0.43) \mathrm{b}$ & $5.06(0.09) \mathrm{a}$ & $6.61(0.12) \mathrm{b}$ \\
Phylogeny groups & & & & \\
Monocotyledon & 59 & $26.34(1.53) \mathrm{b}$ & $3.58(0.21) \mathrm{b}$ & $7.40(0.41) \mathrm{a}$ \\
Dicotyledon & 692 & $35.64(0.49) \mathrm{a}$ & $5.21(0.09) \mathrm{a}$ & $6.84(0.13) \mathrm{a}$ \\
Sites & & & & \\
Maqu & & & & \\
Luqu & 277 & $37.67(0.81) \mathrm{a}$ & $5.59(0.14) \mathrm{a}$ & $6.74(0.13) \mathrm{b}$ \\
Hezuo & 188 & $32.17(0.84) \mathrm{b}$ & $4.68(0.16) \mathrm{b}$ & $6.88(0.27) \mathrm{b}$ \\
Xiahe & 137 & $34.18(1.26) \mathrm{b}$ & $5.10(0.23) \mathrm{a}$ & $6.71(0.40) \mathrm{b}$ \\
\hline
\end{tabular}

$n$ represents the number of samples. SE in brackets is the standard error. Different letters denote significant differences at the 0.05 level.

concentrations ranged from $22.62 \mathrm{mg} \mathrm{g}^{-1}$ for graminoids to $57.08 \mathrm{mg} \mathrm{g}^{-1}$ for $\mathrm{N}$-fixing species, whereas $\mathrm{P}$ concentrations ranged from $3.17 \mathrm{mg} \mathrm{g}^{-1}$ for graminoids to $5.21 \mathrm{mg} \mathrm{g}^{-1}$ for dicotyledon. In contrast, N:P ratios did not show significant difference, except for the two N-fixing groups. N-fixers had higher $\mathrm{N}: \mathrm{P}$ ratios (11.33) than non-fixers (6.61). Furthermore, the geometric mean values of $\mathrm{N}$ and $\mathrm{P}$ concentrations and $\mathrm{N}: \mathrm{P}$ ratios among the four altitude zones were confined to a relatively modest numerical range. Specifically, the $\mathrm{N}$ concentration ranged from $32.17 \mathrm{mg} \mathrm{g}^{-1}$ in Luqu to $37.67 \mathrm{mg} \mathrm{g}^{-1}$ in Maqu, whereas the $\mathrm{P}$ concentration ranged from $4.60 \mathrm{mg} \mathrm{g}^{-1}$ in Xiahe to $5.59 \mathrm{mg}$ $\mathrm{g}^{-1}$ in Maqu; N:P ratios ranged from 6.71 in Hezuo to 7.33 in Xiahe (Table 1).

Across the entire dataset, the numerical value of the $\mathrm{N}$ vs. $\mathrm{P}$ scaling exponent was $0.73(n=751,95 \% \mathrm{CIs}=0.69$ $0.77, r^{2}=0.38, P<0.001$ ) (Figure 3). In the case of the taxonomic groups, the numerical values of scaling exponents varied significantly $(P<0.001)$ among annuals $(0.60)$, perennials (0.75), N-fixers (0.54), non-N-fixers (0.67), monocots (0.87), and dicots (0.71) (Table 2). However, the numerical values of the scaling exponent for forbs (0.72) and graminoids (0.69) showed no significant difference $(P>0.05)$. Moreover, the scaling exponents for $\mathrm{N}$ vs. $\mathrm{P}$ numerically differed along the altitudinal gradient (Table 3 and Figure 4), e.g., the scaling exponent decreased from 0.88 in the high altitude Maqu zone to 0.63 in the low altitude Xiahe zone.

\section{DISCUSSION}

\section{N, P Concentrations and N:P Ratios in Seeds}

The data presented here indicate that the arithmetic mean values of seed $\mathrm{N}$ and $\mathrm{P}$ concentrations (36.91 and $5.58 \mathrm{mg}$ $\left.\mathrm{g}^{-1}\right)$ are higher than leaves $\left(29.20\right.$ and $\left.2.0 \mathrm{mg} \mathrm{g}^{-1}\right)$ reported by $\mathrm{He}$ et al. (2008) and fine roots (11.09 and $0.91 \mathrm{mg} \mathrm{g}^{-1}$ ) reported by Geng et al. (2014) for herbaceous species in an alpine meadow. This finding is consistent with the fact that germinating seeds manifest relatively higher metabolic activity and require more nutrient resources for rapid germination compared to leaves or fine roots ( $\mathrm{Bu}$ et al., 2008) until seedlings become autotrophic and established during a short growing season (Soriano et al., 2011; Bewley, 1997; Bewley et al., 2013). In this respect, the data support the growth rate hypothesis, i.e., fast-growing herbaceous species have higher $\mathrm{N}$ and $\mathrm{P}$ concentrations and lower $\mathrm{N}: \mathrm{P}$ ratios (Sterner and Elser, 2002).
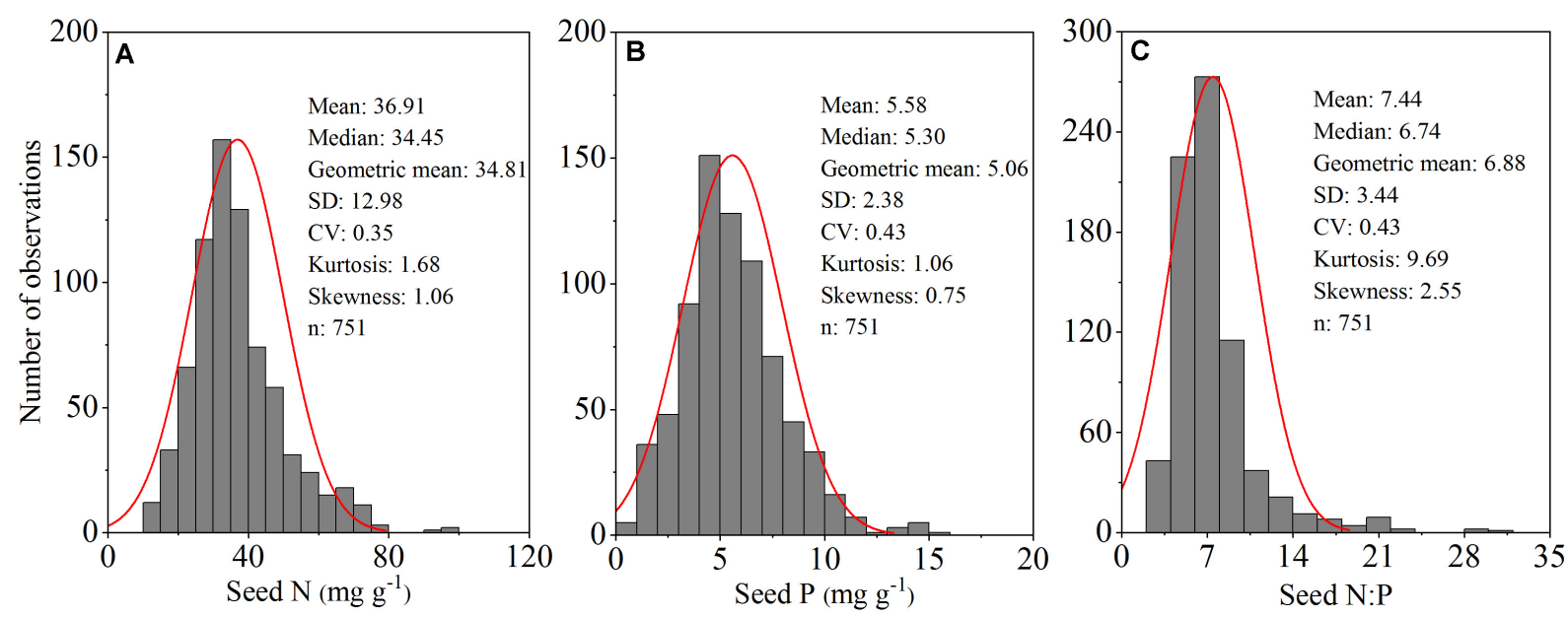

FIGURE 2 | Frequency distribution of seed nitrogen $(\mathrm{N})\left(\mathrm{mg} \mathrm{g}^{-1}\right) \mathbf{( A )}$; phosphorus (P) $\left(\mathrm{mg} \mathrm{g}^{-1}\right)$ (B) and N:P ratios (C) for all 253 herbaceous species in an alpine meadow on the northeast Tibetan Plateau. 


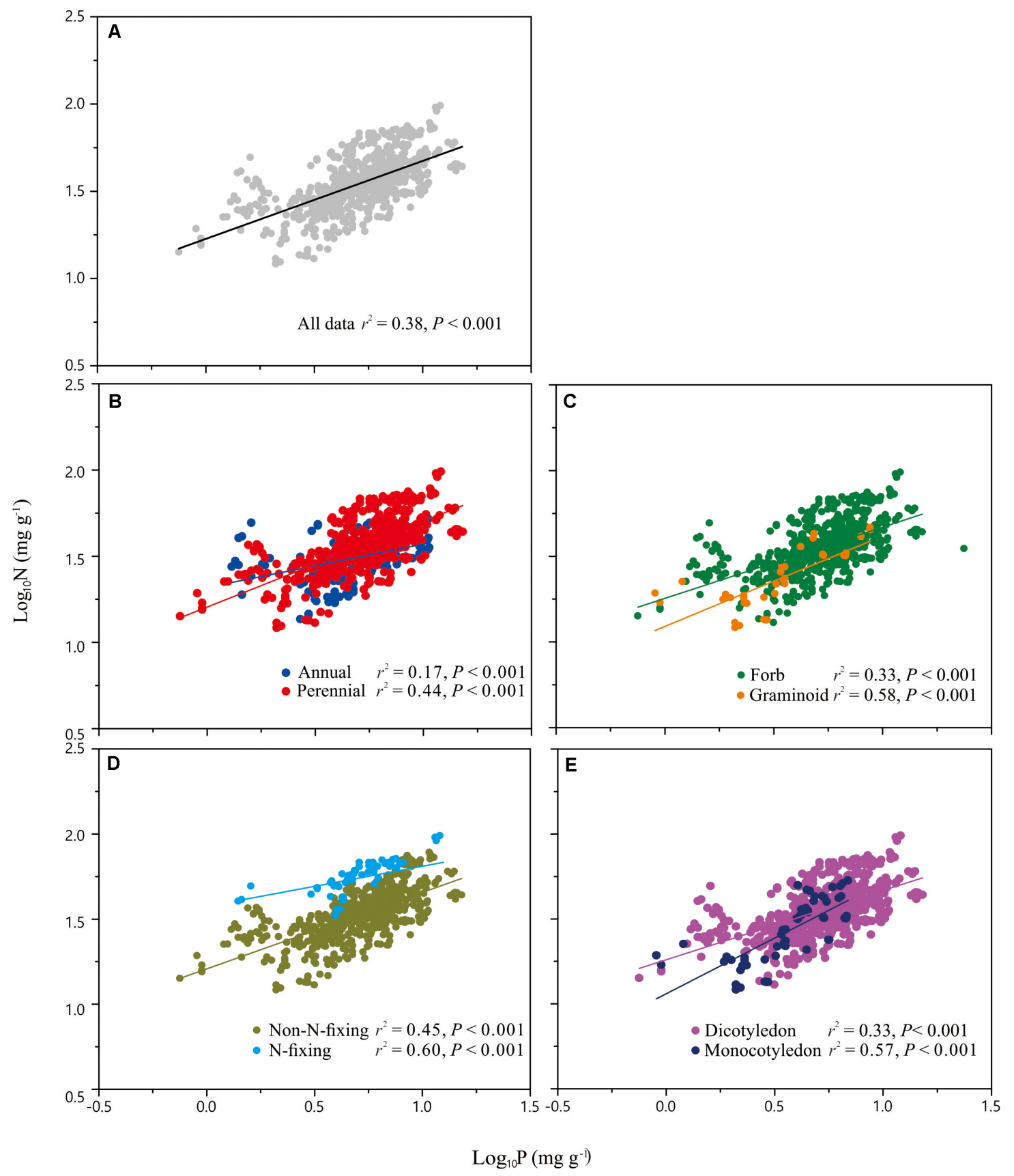

FIGURE 3 | Scaling relationships of seed nitrogen (N) vs. phosphorus (P) for the entire data set (A), and for plants in two life form groups (annual, perennial) (B), two functional groups (forb, graminoid) (C), two $\mathrm{N}$-fixation groups ( $\mathrm{N}$-fixing, non- $\mathrm{N}$-fixing) (D) and two phylogeny groups (monocotyledon, dicotyledon) (E). Statistical parameters for reduced major axis (RMA) regressions are provided in Table $\mathbf{2}$.

Seed $\mathrm{N}$ and $\mathrm{P}$ concentrations varied across major taxonomic groups (Table 1). These differences may simply reflect divergence in nutrient use and metabolic strategies. For example, higher $\mathrm{N}$ concentrations are observed for perennial species compared to annual species. This result is in agreement with the study of Bu et al. (2008) who suggest that higher seed $\mathrm{N}$ content is positively correlated with germination success. The seeds of $\mathrm{N}$-fixing species have significantly higher $\mathrm{N}$ concentrations than
non-N-fixing species owing to their ability to absorb $\mathrm{N}$ in fine roots (McCormack et al., 2015) and also perhaps because of the high metabolic cost of N-fixation (Wardle and Greenfield, 1991). Higher $\mathrm{N}$ and $\mathrm{P}$ concentrations occur in forbs than in graminoids, supporting the idea that seeds of forbs tend to germinate more rapidly and produce more vigorous seedlings compared to the seeds of grasses (Ching and Rynd, 1978). Similarly, Dicotyledon tend to have higher $\mathrm{N}$ and $\mathrm{P}$ concentrations than monocotyledon, 
TABLE 2 | Summary of reduced major axis (RMA) regression statistics for seed N vs. seed $\mathrm{P}$ concentrations for different taxonomic groups (all relations are significant at $P<0.001$ ).

\begin{tabular}{lcccccc}
\hline Taxonomic group & $\boldsymbol{n}$ & Intercept & Exponent & Low Cl & High Cl & $\boldsymbol{r}^{\mathbf{2}}$ \\
\hline All & 751 & 1.03 & 0.73 & 0.69 & 0.77 & 0.38 \\
Life form groups & & & & & & \\
Annual & 188 & 1.08 & $0.60 \mathrm{~b}$ & 0.52 & 0.58 & 0.17 \\
Perennial & 563 & 1.03 & $0.75 \mathrm{a}$ & 0.7 & 0.79 & 0.44 \\
Functional groups & & & & & & \\
Forb & 714 & 1.04 & $0.72 \mathrm{a}$ & 0.68 & 0.76 & 0.33 \\
Graminoid & 37 & 1.01 & $0.69 \mathrm{a}$ & 0.54 & 0.85 & 0.58 \\
N-fixation groups & & & & & & \\
N-fixing & 57 & 1.38 & $0.54 \mathrm{~b}$ & 0.45 & 0.63 & 0.60 \\
Non-N-fixing & 694 & 1.05 & $0.67 \mathrm{a}$ & 0.63 & 0.71 & 0.45 \\
Phylogeny groups & & & & & & \\
Monocotyledon & 59 & 0.94 & $0.87 \mathrm{a}$ & 0.85 & 1.03 & 0.57 \\
Dicotyledon & 692 & 1.04 & $0.71 \mathrm{~b}$ & 0.67 & 0.75 & 0.33 \\
\hline
\end{tabular}

$n$ represent the number of observations, and letters denote significant differences in exponents based on a likelihood ratio test. All data were $\log _{10^{-}}$ transformed for analysis.

TABLE 3 | Summary of reduced major axis (RMA) regression statistics for seed $\mathrm{N}$ vs. seed $\mathrm{P}$ concentrations for four altitudinal zones (all relations are statistically significant at $P<0.001$ ).

\begin{tabular}{lccccccc}
\hline Site & Altitude & $\boldsymbol{n}$ & Intercept & Exponent & Low Cl & High Cl & $\boldsymbol{r}^{\mathbf{2}}$ \\
\hline Maqu & $3400-4200$ & 277 & 0.98 & $0.88 \mathrm{a}$ & 0.74 & 0.87 & 0.55 \\
Luqu & $3000-3400$ & 188 & 1.00 & $0.76 \mathrm{~b}$ & 0.67 & 0.85 & 0.28 \\
Hezuo & $2600-3000$ & 137 & 1.05 & $0.68 \mathrm{c}$ & 0.58 & 0.78 & 0.25 \\
Xiahe & $2000-2600$ & 149 & 1.11 & 0.63c & 0.55 & 0.71 & 0.37
\end{tabular}

Letters denote significant differences in exponents based on a likelihood ratio test. All data were $\log _{10}$-transformed for analysis.

perhaps as a result of differences in how nutrient reserves are stored (Bonfil, 1998). The N:P ratios of the seeds collected in this study do not vary across major taxonomic groups, with the exception of $\mathrm{N}$-fixers. The relative constancy of seed N:P ratios across major taxonomic groups may reflect a fundamental constraint on seed $\mathrm{N}$ and $\mathrm{P}$ stoichiometry.

Finally, variations in seed $\mathrm{N}$ and $\mathrm{P}$ concentrations and $\mathrm{N}: \mathrm{P}$ ratios among the four altitude zones are statistically discernable. The high $\mathrm{N}$ and $\mathrm{P}$ concentrations in the Maqu zone were significantly higher than those in the other three regions. This may reflect an adaptive strategy to deal with low temperatures and a very short growing season (Bu et al., 2016). Under any circumstances, our data support the temperatureplant physiological hypothesis (Reich and Oleksyn, 2004), which states that higher $\mathrm{N}$ and $\mathrm{P}$ concentrations at low temperatures offset reductions in metabolic reaction rates and enhance cold hardiness.

\section{The $\mathbf{N}$ vs. P Scaling Exponent Across Major Taxonomic Groups}

The analysis of the pooled data set indicates that the numerical value of the scaling exponent governing the seed $\mathrm{N}$ vs. $\mathrm{P}$ scaling relationship is 0.73 . This value is consistent with $3 / 4$ power "rule" reported for leaves (Reich and Oleksyn, 2004; Niklas, 2006a), and is significantly different from the numerical values reported by other workers for leaves (Wright et al., 2004; Reich et al., 2010; Tian et al., 2018) or for fine roots (Wang et al., 2019). The observed 3/4-power "rule" for seeds indicates that $\mathrm{P}$ concentrations increase faster than $\mathrm{N}$ concentrations (which may reflect the fact that protein synthesis during early seed germination primarily relies on mRNA reserves which are P-rich), which once again supports the growth rate hypothesis of Sterner and Elser (2002). In addition, this value is inconsistent with those of Kerkhoff et al. (2006), who found that the $\mathrm{N}$ vs. $\mathrm{P}$ scaling exponent in reproductive structures is close to 1. However, it must be noted that, compared to previous studies using extensive global data sets for leaves and fine roots, our data come only from herbaceous species growing in an alpine meadow.

Although more data for different species and biomes are required to determine whether the seed $\mathrm{N}$ vs. $\mathrm{P}$ scaling exponent interspecifically converges onto a "canonical" value, it is clear that the numerical values of the scaling exponent differs significantly among contrasting taxonomic groups (Table 2, Figure 3). For example, compared to annual species, perennial species have numerically higher $\mathrm{N}$ vs. $\mathrm{P}$ scaling exponents ( 0.60 vs. 0.75$)$, suggesting that the short life cycle of annual species requires rapid growth rates. The $\mathrm{N}$ vs. $\mathrm{P}$ scaling exponent for $\mathrm{N}$-fixing species (0.54) is lower than non-Nfixing species (0.67), indicating that $\mathrm{N}$-fixing species with higher $\mathrm{N}: \mathrm{P}$ ratios may have a competitive advantage for $\mathrm{P}$ absorption over non-N-fixing species. The numerically smaller $\mathrm{N}$ vs. $\mathrm{P}$ scaling exponent observed for dicotyledon (0.71) relative to monocotyledon (0.87) might reflect differences in the ways nutrients are stored and provided (i.e., storage in cotyledons vs. endosperm), thereby providing different nutrient allocation strategies resulting from evolutionary selection pressures on plant physiology (He et al., 2006). However, in the case of the two functional groups, the numerical value of scaling exponents did not differ between forbs and graminoids. In this context, it is also important to note that the scaling exponents reported here for graminoids have broad 95\% CIs (i.e., 0.85 and 0.54) which include the 0.72 scaling exponent observed for forbs. Therefore, more data from graminoids are needed.

\section{N vs. P Scaling Exponent Along the Altitudinal Gradient}

The numerical value of the seed $\mathrm{N}$ vs. $\mathrm{P}$ scaling exponent varied significantly and declined from the high altitude Maqu zone $(0.88)$ to the low altitude Xiahe zone (0.63) (Table 3, Figure 4). We suggest that this phenomenology reflects different strategies to cope with lower temperatures and shorter growing seasons with increasing altitude (Bazzaz and Grace, 1997). In Xiahe, the relatively high growing season temperature and length and high soil $\mathrm{N}$ and $\mathrm{P}$ availability can promote rapid germination. In contrast, with increasing altitude, lower temperatures can depress the absorption of soil nutrients, thereby 


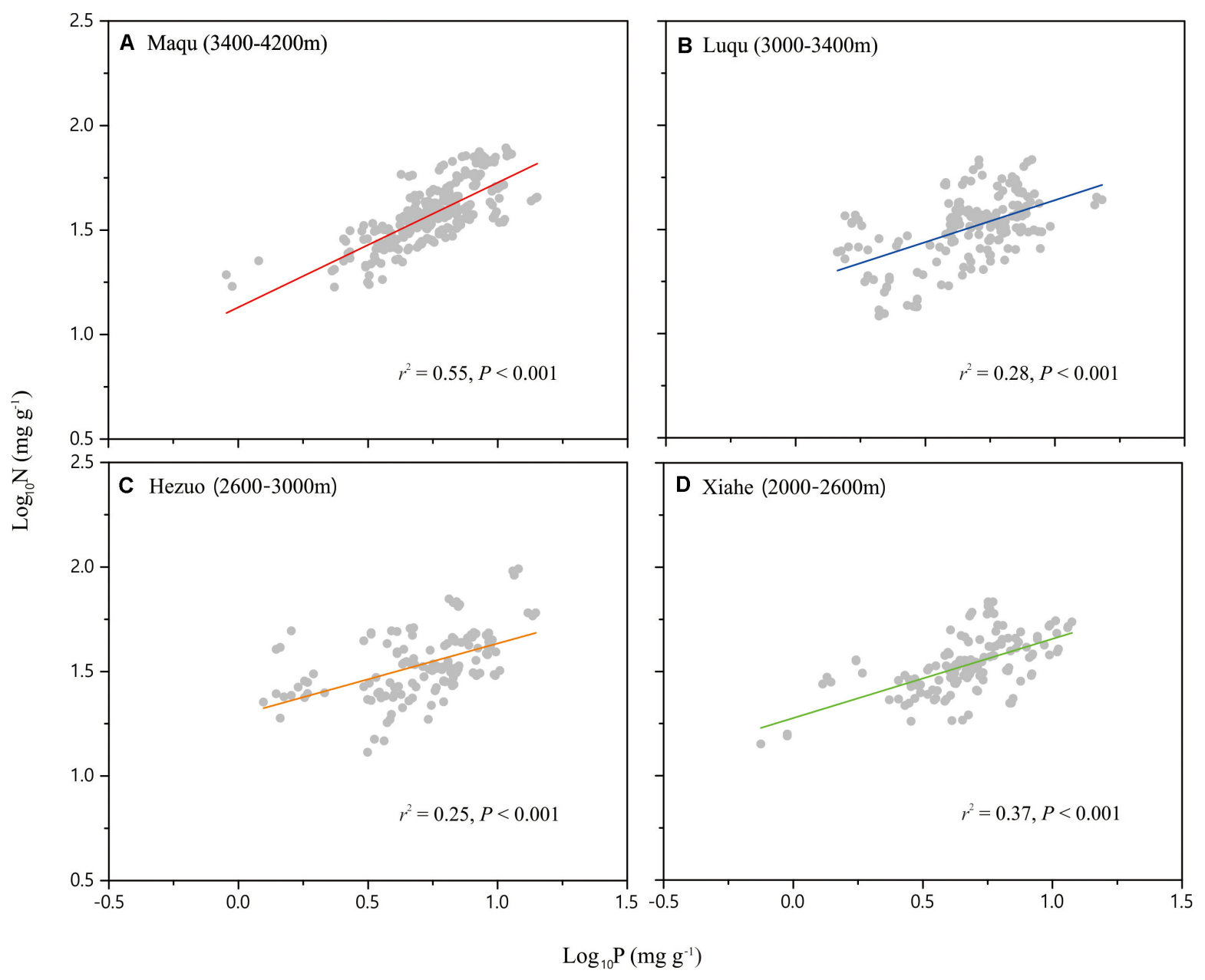

FIGURE 4 | Scaling relationships of seed nitrogen (N) vs. phosphorus (P) in an alpine meadow for the four altitude zones: Maqu (A), Luqu (B), Hezuo (C), and Xiahe (D). Statistical parameters for reduced major axis (RMA) regressions are provided in Table 3.

reduce in the availability of $\mathrm{N}$ and $\mathrm{P}$ during germination (Aerts and Chapin, 2000).

\section{CONCLUSION}

In summary, this study shows that the numerical value of the seed $\mathrm{N}$ vs. $\mathrm{P}$ scaling exponent differs across major taxonomic groups and declines from high to low altitude. Based on these data, we suggest that herbaceous species in alpine meadow allocate $\mathrm{N}$ and $\mathrm{P}$ in seeds to maximize germination and seedling success in response to differences in their environment. These results advance our understanding of plant seed allocation strategies, and have important implications for modeling early plant growth.

\section{DATA AVAILABILITY STATEMENT}

The original contributions presented in the study are included in the article/supplementary materials, further inquiries can be directed to the corresponding author/s.

\section{AUTHOR CONTRIBUTIONS}

$\mathrm{ZW}, \mathrm{HH}$, and $\mathrm{KN}$ conceived the idea and designed the research. ZW, MW, and HB collected the data. All authors performed the data analysis, wrote the manuscript and gave final approval for publication.

\section{FUNDING}

This study was financially supported by the National Key R\&D Program of China (2019YFC0507701) and the Nature Science Fund of China (31770448).

\section{ACKNOWLEDGMENTS}

We are grateful to Dr. Xianhui Zhou and Dr. Xudong Liu for the help with seed collection, and Miss. Wei Liu and Dr. Xiaoming Shi for determining the $\mathrm{N}$ and $\mathrm{P}$ concentrations. 


\section{REFERENCES}

Adler, P. B., Salguero-Gómez, R., Compagnoni, A., Hsu, J. S., Ray-Mukherjee, J., Mbeau-Ache, C., et al. (2014). Functional traits explain variation in plant life history strategies. Proc. Natl. Acad. Sci. U S A. 101, 11001-11006.

Aerts, R., and Chapin, F. S. III (2000). The mineral nutrition of wild plants revisited: a re-evaluation of processes and patterns. Adv. Ecol. Res. 30, 1-67. doi: 10.1016/s0065-2504(08)60016-1

Ågren, G. I. (2004). The C:N:P stoichiometry of autotrophs-theory and observations. Ecol. Lett. 7, 185-191. doi: 10.1111/j.1461-0248.2004.00567.x

Bazzaz, A. F., and Grace, J. (1997). Plant Resource Allocation. San Diego: Academic Press.

Bewley, J. D. (1997). Seed germination and dormancy. Plant Cell Online 9, 10551066.

Bewley, J. D., Bradford, K. J., Hilhorst, H. W. M., and Nonogaki, H. (2013). Seeds: Physiology of Development, Germination and Dormancy, 3rd Edn. New York, NY: Springer.

Bonfil, C. (1998). The effects of seed size, cotyledon reserves, and herbivory on seedling survival and growth in Quercus rugosa and Q. laurina (Fagaceae). Am. J. Bot. 85, 79-87. doi: 10.2307/2446557

Bu, H. Y., Du, G. Z., Chen, X. L., Xu, X. L., Liu, K., and Wen, S. J. (2008). Community-wide germination strategies in an alpine meadow on the eastern Qinghai-Tibetan Plateau: phylogenetic and life-history correlates. Plant Ecol. 195, 87-98. doi: 10.1007/s11258-007-9301-1

Bu, H. Y., Jia, P., Qi, W., Liu, K., Xu, D. H., Ge, W. J., et al. (2018). The effects of phylogeny, life-history traits and altitude on the carbon, nitrogen, and phosphorus contents of seeds across 203 species from an alpine meadow. Plant Ecol. 219, 737-748. doi: 10.1007/s11258-018-0830-6

Bu, H. Y., Wang, X. J., Zhou, X. H., Qi, W., Liu, K., Ge, W. J., et al. (2016). The ecological and evolutionary significance of seed shape and volume for the germination of 383 species on the eastern Qinghai-Tibet Plateau. Folia Geobot. 51, 333-341. doi: 10.1007/s12224-016-9271-y

Bu, H. Y., Zhang, Y. M., Zhao, D., Wang, S. Y., Jia, P., Qi, W., et al. (2019). The evolutionary correlation associated with seed mass and altitude on nutrient allocation of seeds. Seed Sci. Res. 29, 38-43. doi: 10.1017/s0960258518000387

Ching, T. M., and Rynd, L. (1978). Developmental differences in embryos of high and low protein wtheat seeds during germination. Plant Physiol. 62, 866-870. doi: $10.1104 / p p .62 .6 .866$

de Frenne, P., Kolb, A., Graae, B. J., Decocq, G., Baltora, S., de Schrijver, A., et al. (2011). A latitudinal gradient in seed nutrients of the forest herb Anemone nemorosa. Plant Biol. 13, 493-501. doi: 10.1111/j.1438-8677.2010.00404.x

Elser, J. J., Acharya, K., Kyle, M., Cotner, J., Makino, W., Markow, T., et al. (2003). Growth rate-stoichiometry couplings in diverse biota. Ecol. Lett. 6, 936-943. doi: 10.1046/j.1461-0248.2003.00518.x

Elser, J. J., Bracken, M. E. S., Cleland, E. E., Gruner, D. S., Harpole, W. S., Hillebrand, H., et al. (2007). Global analysis of nitrogen and phosphorus limitation of primary producers in freshwater, marine, andterrestrial ecosystems. Ecol. Lett. 10, 1135-1142. doi: 10.1111/j.1461-0248.2007. 01113.x

Elser, J. J., Sterner, R. W., Gorokhova, E., Fagan, W. F., Markow, T. A., Cotner, J. B., et al. (2000). Biological stoichiometry from genes to ecosystems. Ecol. Lett. 3, 540-550. doi: 10.1046/j.1461-0248.2000.00185.x

Geng, Y., Wang, L., Jin, D. M., Liu, H. Y., and He, J. S. (2014). Alpine climate alters the relationships between leaf and root morphological traits but not chemical traits. Oecologia 175, 445-455. doi: 10.1007/s00442-014-2919-5

Güsewell, S. (2004). N:P ratios in terrestrial plants: variation and functional significance. New Phytol. 164, 243-266. doi: 10.1111/j.1469-8137.2004. 01192.x

Han, W. X., Fang, J. Y., Guo, D. L., and Zhang, Y. (2005). Leaf nitrogen and phosphorus stoichiometry across 753 terrestrial plant species in China. New Phytol. 168, 377-385. doi: 10.1111/j.1469-8137.2005.01530.x

He, J. S., Flynn, D. F. B., Wolfe-Bellin, K., Fang, J., and Bazzaz, F. A. (2005). $\mathrm{CO}_{2}$ and nitrogen, but not population density, alter the size and $\mathrm{C} / \mathrm{N}$ ratio of Phytolacca americana seeds. Funct. Ecol. 19, 437-444. doi: 10.1111/j.1365-2435. 2005.00981.x

He, J. S., Wang, L., Flynn, D. F. B., Wang, X. P., Ma, W. H., and Fang, J. Y. (2008). Leaf nitrogen:phosphorus stoichiometry across Chinese grassland biomes. Oecologia 155, 301-310. doi: 10.1007/s00442-007-0912-y
He, J. S., Wang, Z. H., Wang, X. P., Schmid, B., Zuo, W. Y., Zhou, M., et al. (2006). A test of the generality of leaf trait relationship on the Tibetan Plateau. New Phytol. 170, 835-848. doi: 10.1111/j.1469-8137.2006.01704.x

Jiménez-Alfaro, B., Silveira, F. A. O., Fidelis Poschlod, P., and Commander, L. E. (2016). Seed germination traits can contribute better to plant community ecology. J. Veg. Sci. 27, 637-645. doi: 10.1111/jvs.12375

Kerkhoff, A. J., Fagan, W. F., Elser, J. J., and Enquist, B. J. (2006). Phylogenetic and growth form variation in the scaling of nitrogen and phosphorus in the seed plants. Am. Nat. 168, E103-E122.

Körner, C. (1989). The nutritional status of plants from high altitudes. A worldwide comparison. Oecologia 81, 379-391. doi: 10.1007/bf00377088

Legendre, P. (2018). Imodel2: Model II Regression. R Package Version 1.73. Available online at: http://CRAN.R-project.org/package=lmodel2 (accessed December 26, 2019).

Lord, J. M. (1994). Variation in Festuca novae-zelandiae (Hace.) Cockayne germination behaviour with altitude of seed source. New Zeal. J. Bot. 32, 227-235. doi: 10.1080/0028825x.1994.10410369

Mathew, J. P., Herbert, S. J., Zhang, S. H., Rautenkranz, A. A. F., and Litchfield, G. V. (2000). Differential response of soybean yield components to the timing of light enrichment. Agron. J. 92, 1156-1161. doi: 10.2134/agronj2000.926 $1156 \mathrm{x}$

McCormack, M. L., Dickie, I. A., Eissenstat, D. M., Fahey, T., Fernandez, C. W., Guo, D. L., et al. (2015). Redefining fine roots improves understanding of below-ground contributions to terrestrial biosphere processes. New Phytol. 207, 505-518. doi: 10.1111/nph.13363

McGroddy, M. E., Daufresne, T., and Hedin, L. O. (2004). Scaling of C:N:P stoichiometry in forests worldwide: implications of terrestrial Redfield-type ratios. Ecology 85, 2390-2401. doi: 10.1890/03-0351

Muthukumar, T., and Udaiyan, K. (2000). The role of seed reserves in arbuscular mycorrhizal formation and growth of Leucaena leucocephala (Lam.) de Wit. and Zea mays L. Mycorrhiza 9, 323-330. doi: 10.1007/s005720050276

Niklas, K. J. (2006a). Plant allometry, leaf nitrogen and phosphorus stoichiometry, and interspecific trends in annual growth rates. Ann. Bot. 97, 155-163. doi: $10.1093 / \mathrm{aob} / \mathrm{mcj} 021$

Niklas, K. J., and Cobb, E. D. (2006b). Biomass partitioning and leaf N, P-stoichiometry: comparisons between tree and herbaceous current-year shoots. Plant Cell Environ. 29, 2030-2042. doi: 10.1111/j.1365-3040.2006. 01578.x

Niklas, K. J., Owens, T., Reich, P. B., and Cobb, E. D. (2005). Nitrogen/phosphorus leaf stoichiometry and the scaling of plant growth. Ecol. Lett. 8, 636-642. doi: 10.1111/j.1461-0248.2005.00759.x

R Development Core Team. (2015). R: a language and environment for statistical computing. Vienna: R Foundation for Statistical Computing.

Reich, P. B., and Oleksyn, J. (2004). Global patterns of plant leaf N and P in relation to temperature and latitude. Proc. Natl. Acad. Sci. U S A. 101, 11001-11006. doi: 10.1073/pnas.0403588101

Reich, P. B., Oleksyn, J., Wright, I. J., Niklas, K. J., Hedin, L., and Elser, J. J. (2010). Evidence of a general 2/3-power law of scaling leaf nitrogen to phosphorus among major groups and biomes. Proc. Roy. Soc. B Biol. Sci. 277, 877-883. doi: $10.1098 /$ rspb.2009.1818

Slot, M., Palow, D. T., and Kitajima, K. (2013). Seed reserve dependency of Leucaena leucocephala seedling growth for nitrogen and phosphorus. Funct. Plant. Biol. 40, 244-250. doi: 10.1071/fp12255

Soriano, D., Orozco-Segovia, A., Márquez-Guzmán, J., Kitajima, K., Gamboa-de Buen, A., and Huante, P. (2011). Seed reserve composition in 19 tree species of a tropical deciduous forest in Mexico and its relationship to seed germination and seedling growth. Ann. Bot. 107, 939-951. doi: 10.1093/aob/mcr041

Sterner, R. W., and Elser, J. J. (2002). Ecological Stoichiometry: The Biology of Elements from Molecules to the Biosphere. Princeton, USA: Princeton University Press.

Tian, D., Yan, Z. B., Niklas, K. J., Han, W. X., Kattge, J., Reich, P. B., et al. (2018). Global leaf nitrogen and phosphorus stoichiometry and their scaling exponent. Nat. Sci. Rev. 5, 728-739. doi: 10.1093/nsr/nwx142

Turnbull, L. A., Philipson, C. D., Purves, D. W., Atkinson, R. L., Cunniff, J., Goodenough, A., et al. (2012). Plant growth ratesand seed sizes: a re-evaluation. Ecology 93, 1283-1289.

Vitousek, P. M. (2004). Nutrient Cycling and Limitation: Hawai'i as a Model System. Princeton, USA: Princeton University Press. 
Vitousek, P. M., Porder, S., Houlton, B. Z., and Chadwick, O. A. (2010). Terrestrial phosphorus limitation: mechanisms, implications, and nitrogen-phosphorus interactions. Ecol. Appl. 20, 5-15. doi: 10.1890/08-0127.1

Vrede, T., Dobberfuhl, D. R., Kooijman, S. A. L. M., and Elser, J. J. (2004). Fundamental connections among organism C:N:P stoichiometry macromolecular composition, and growth. Ecology 85, 1217-1229. doi: 10 . 1890/02-0249

Wang, Z. Q., Huang, H., Li, X. W., Mao, K. S., Ran, J. Z., and Deng, J. M. (2018). Allocation of nitrogen and phosphorus within and between needles, stems and roots of Picea seedlings. Nord. J. Bot. 36:e01952. doi: 10.1111/njb.01952

Wang, Z. Q., Yu, K. L., Lv, S. Q., Niklas, K. J., Mipam, T. D., Crowther, T. W., et al. (2019). The scaling of fine root nitrogen versus phosphorus in terrestrial plants: a global synthesis. Funct. Ecol. 33, 2081-2094. doi: 10.1111/1365-2435.13434

Wardle, D. A., and Greenfield, L. G. (1991). Release of mineral nitrogen from plant root nodules. Soil. Biol. Biochem. 23, 827-832. doi: 10.1016/0038-0717(91) 90093-y

Warton, D. I., Wright, I. J., Falster, D. S., and Westoby, M. (2006). Bivariate line-fitting methods for allometry. Biol. Rev. 81, 259-291. doi: 10.1017/ s1464793106007007

Wright, I. J., Westoby, M., Ackerly, D. D., Baruch, Z., Bongers, F., Cavender-Bares, J., et al. (2004). The worldwide leaf economics spectrum. Nature 428, 821-827.

Xu, G., Singh, S., Barnaby, J., Buyer, J., Reddy, V., and Sicher, R. (2016). Effects of growth temperature and carbon dioxide enrichment on soybean seed components at different stages of development. Plant. Physiol. Biochem. 108, 313-322. doi: 10.1016/j.plaphy.2016.07.025
Yuan, Z. Y., Chen, H. Y. H., and Reich, P. B. (2011). Global-scale latitudinal patterns of plant fine-root nitrogen and phosphorus. Nat. Commun. 2:344. doi: $10.1038 /$ ncomms1346

Zhang, C. H., Willis, C. G., Burghardt, L. T., Qi, W., Liu, K., de Moura Souza-Filho, P. R., et al. (2014). The community-level effect of light on germination timing in relation to seed mass: a source of regeneration niche differentiation. New Phytol. 204, 496-506. doi: 10.1111/nph.12955

Zhang, J. H., He, N. P., Liu, C. C., Li, X., Yu, Q., and Yu, G. R. (2018). Allocation Strategies for Nitrogen and Phosphorus in Forest Plants. Oikos 127, 1506-1514. doi: 10.1111/oik.05517

Zhao, N., Yu, G. R., He, N. P., Xia, F. C., Wang, Q. F., Wang, R. L., et al. (2016). Invariant allometric scaling of nitrogen and phosphorus in leaves, stem, and fine roots of woody plants along an altitudinal gradient. J. Plant Res. 129, 647-657. doi: $10.1007 /$ s10265-016-0805-4

Conflict of Interest: The authors declare that the research was conducted in the absence of any commercial or financial relationships that could be construed as a potential conflict of interest.

Copyright (c) 2020 Wang, Bu, Wang, Huang and Niklas. This is an open-access article distributed under the terms of the Creative Commons Attribution License (CC BY). The use, distribution or reproduction in other forums is permitted, provided the original author(s) and the copyright owner(s) are credited and that the original publication in this journal is cited, in accordance with accepted academic practice. No use, distribution or reproduction is permitted which does not comply with these terms. 